\title{
The use of discovery learning model with RME approach viewed from interpersonal intelligence
}

\author{
Desty Ratna Permatasari, Heribertus Soegiyanto, Budi Usodo \\ Master's Degree Program in Primary School Teacher Education, Sebelas Maret University, Indonesia
}

\begin{tabular}{l} 
Article Info \\
\hline Article history: \\
Received Aug 03, 2018 \\
Revised Des 10, 2018 \\
Accepted Jan 08, 2019 \\
\hline
\end{tabular}

\section{Keywords:}

Discovery learning Interpersonal intelligence Realistic mathematic education

\begin{abstract}
This research is aimed at finding out: 1) the influence of discovery learning model with RME approach on Mathematics learning achievement; 2) the influence of interpersonal intelligence on Mathematics learning achievement; 3) the interaction between discovery learning model with RME approach and interpersonal intelligence on Mathematics learning achievement. The research was conducted at one of the state Elementary Schools in Banjarsari sub-district, Surakarta. The method used in this research was quasiexperimental method with $2 \times 3$ factorial design. Hypothesis test was done by two-way variance ANOVA test with different cells. It can be concluded that the discovery learning model with RME approach gives better influence on the Mathematics learning achievement than the direct learning model. Students having high interpersonal intelligence category get better Mathematics learning achievement than those having medium and low category. The students having medium interpersonal intelligence get better Mathematics achievement than those having low category. There is no interaction between learning model and interpersonal intelligence on Mathematics learning achievement.
\end{abstract}

Copyright (ㅇ 2019 Institute of Advanced Engineering and Science. All rights reserved.

\section{Corresponding Author: \\ Desty Ratna Permatasari, \\ Department of Primary School Teacher Education, \\ Faculty of Postgraduate, \\ Sebelas Maret University, \\ Ir. Sutami Street No. 36 A, Surakarta, Indonesia. \\ Email: destyratnapermata@gmail.com}

\section{INTRODUCTION}

Education is used as the effort to develop the learners' potential through the learning activities. Basically, the students get some disciplines in formal education one of them is Mathematics course. Mathematics is a subject that is closely related to daily life; however, there are still many students in elementary school who find it difficult to understand the concepts. It affects the students' low mathematics learning achievement. Based on the 2015 TIMSS (Trends in International Mathematics and Science Study) report, Indonesia is ranked 36th out of 49 countries. In 2015, the survey of PISA (Program for International Student Assessment) also shows that Indonesian students' Mathematics achievement ranking is in 69th position out of 76 countries.

The low students' achievement in Mathematics is caused by the external factors and internal factors. One of the external factors is the lack of use of innovative learning models by the teachers, especially on Mathematics subjects. As a result, the students cannot solve the mathematical problems that they encounter, especially if they face Mathematics problems related to their daily life. Therefore, teachers should design and implement various models of appropriate learning on each subject matter.

One of the learning models that can be used as a solution is a discovery learning model. DL is a model for developing the students' active learning by finding out the solution by themselves, self- 
investigating. The results will be long-lasting in their memory and not be easily forgotten by the students [1]. Discovery learning is an activity to strengthen students in learning independently and to apply what they learn and ultimately produce effective learning [2]. Discovery learning encourages students to hypothesize better and deeper when they are asked to find and build important information for themselves [3]. In his research, Balim concludes that discovery learning model requires the students to comment on concepts, information, and events by discussing and asking questions and reaching the information itself, in other words, finding solutions through practice [4]. Stages or procedures in DL are stimulation, problem statement, data collection, data processing, verifycation, and generalization [5].

Based on the above-mentioned research results, it can be concluded that discovery learning is one of the learning models that makes the students active to create the effective classroom. The effectiveness of the implementation of discovery learning model included in the learning mathematics can be effective, especially if it is combined with the learning approach that is devoted to learning Mathematics, such as Realistic Mathematic Education. Sumantri reveals that the realistic Mathematics stated in the RME approach is school Mathematics that is implemented by placing the students' reality and experience as the starting point in learning [6]. The students' initial experience and knowledge helped him in studying an abstract material such as Mathematics. RME focuses on developing conceptual understanding through "doing mathematics"; therefore, RME provides the examples from the environment or experience or knowledge [7]. Realistic concepts in RME means that the students' experience or knowledge are assumed to make them have better understanding about the various concepts in Mathematics. It is in line with Arshaytamby' finding that RME is a special teaching and learning theory that is appropriate and dependent to be applied in the real world. The instruction is begun from the students' own experience; therefore, the students can participate in learning activities to make the more meaningful Mathematics lessons. Answering real questions will be more meaningful by utilizing interactive instructions. The demand for being active students is a typical feature of RME, so the teacher only directs the students' activities [8]. The core of RME is learning activities starting from the real world; therefore, the students can involve in the learning process significantly. The teachers play the main roles as mentor and facilitator for the students in the process of reconstructing ideas and Mathematical concepts [9].

The implementation of discovery learning model with RME approach in this research was conducted in groups due to the more information that will be got by the students. It can be considered that discovery learning is a learning model putting the students as the active learners and the teacher as the only mentor or facilitator. Students should actively build their own knowledge by interacting with others and the environment. Interaction and cooperation among students will be very helpful in learning activities using discovery learning model with RME approach. Cooperation in groups requires the students to be able to adapt with others. This ability is also called as interpersonal intelligence. Gardner suggests that interpersonal intelligence implies the person's ability to understand the others' intentions, motivations, and desires that they will effectively work with. [10] In the cooperative activities, the students of the interpersonal group have interpersonal interactions, like peer tutors, and attend a group brainstorming session [11]. Interpersonal intelligence is in line with current communication and collaboration learning objectives, critical thinking and problem solving [12]. Through this exposure, it is understandable that the discovery learning model with the RME approach to the learning atmosphere demands the students' activeness and independence. It is appropriate to be applied in the groups having the ability to adapt and interact with the environment in different categories.

This study is aimed at finding out the effect of discovery learning using RME approach, the students' interpersonal intelligence, and the students' independent performance in Mathematics learning achievement. This research is conducted to answer the following questions:

a. How is the influence of discovery learning using RME approach to Mathematics learning achievement of elementary school students in Banjarsari?

b. How is the influence of interpersonal intelligence to their Mathematics learning in the elementary school in Banjarsari?

c. Is there any interaction between discovery learning model using RME approach and interpersonal intelligence to the students' Mathematics learning achievement in the elementary school in Banjarsari?

\section{RESEARCH METHOD}

The population of this study was the students of the fifth-grade in SD Negeri Banjarsari sub-district Surakarta consisting of 47 elementary schools. The sample of this research was the students of the fifth-grade in 6 elementary schools. The sample was taken by using stratified cluster random sampling technique. The type of research is quasi-experiment. The data collection techniques used test to collect Mathematics learning achievement data and questionnaire to find out the interpersonal intelligence data. The number of 
achievement test was 25 multiple choice items. A questionnaire was used to collect the interpersonal intelligence data consisting of 25 items. The results will be categorized into three categories, namely high, medium, and low category. Normality was performed using Saphiro Wilk test and homogeneity of variance using Levene test. Meawhile, the data analysis technique of learning achievement used two-way variance analysis with unequal cell and post-anava test using Scheffe method [13].

\section{RESULTS AND ANALYSIS}

The instrument was used to collect the data of Mathematics learning achievement consisting of 25 test items in the form of multiple choices that was given to the students both in experimental and control class. Before conducting hypothesis test using two-way ANOVA, two prerequisite tests were conducted, they are normality and homogeneity test of learning achievement data. Normality and homogeneity test of student's Mathematics learning achievement data were done using SPSS with significance level 5\%. The result of normality test of the students' Mathematics learning achievement is shown in Table 1 below.

Table 1. Normality Test of Mathematics Achievement Test

\begin{tabular}{cccc}
\hline & & Kolmogorov-Smirnov $^{\mathrm{a}}$ & \\
& Statistic & df & Sig. \\
\hline DL RME & .084 & 83 & .200 \\
DIRECTLY & .089 & 94 & .062 \\
\hline
\end{tabular}

Table 1. shows that experimental class that used discovery learning model with RME approach and control class used direct learning model in which the the significant value is $>0.05$ is $0.200>0.05$, and $0.062>0.05$. Therefore, it can be concluded that the sample of achievement tests comes from a normal distributed population. The homogeneity test of student achievement test data is shown in Table 2 below.

Table 2. Homogeneity Test of Mathematics Achievement Test

\begin{tabular}{ccccc}
\hline Statistic & Levene & df1 & df2 & Sig \\
\hline .126 & 2 & 174 & .882 \\
\hline
\end{tabular}

Table 2. Shows that the significant value is $=0.882>0.05$. Based on the homogeneity test results, it is concluded that the sample has the same or homogeneous variance. In this study, the data were analyzed using two-way ANOVA shown in table 3 with the following results.

Table 3. Hypothesis Test

\begin{tabular}{ccccccc}
\hline Source & Type III Sum of Squares & df & Mean Square & F & Sig. & Partial Eta Squared \\
\hline Corrected Model & $19636.957^{\mathrm{a}}$ & 5 & 3927.391 & 11.554 & .000 & .253 \\
Intercept & 519500.421 & 1 & 519500.421 & $1.528 \mathrm{E} 3$ & .000 & .899 \\
Model & 11762.671 & 1 & 11762.671 & 34.606 & .000 & .168 \\
KI & 7215.487 & 2 & 3607.743 & 10.614 & .000 & .110 \\
Model * KI & 756.504 & 2 & 378.252 & 1.113 & .331 & .013 \\
Error & 58123.223 & 171 & 339.902 & & & \\
Total & 622576.000 & 177 & & & & \\
Corrected Total & 77760.181 & 176 & & & & \\
\hline
\end{tabular}

Based on Table 3, which is the result of hypothesis test, it can be concluded that: 1) the influence of discovery learning model with RME approach toward Mathematics learning achievement has the value of $\mathrm{F}$ obtained $=34.606$ with significance $=0.000<0.05$, so $\mathrm{H}_{0}$ is rejected. It means that there is a difference between students' Mathematics learning achievement in experimental class using discovery learning model with RME approach and students' Mathematics learning achievement in control class using direct learning.; 2) The influence of interpersonal intelligence on Mathematics learning achievement has a value of $F$ obtained of 10.614 and significance $=0.000<0.05$. Therefore, it can be concluded that there are differences in Mathematics learning achievement in each category of interpersonal intelligence; 3) Based on table 3, in column Model $*$ KI obtained sig. $=0.331>0.05$, it can be concluded that there is no interaction between 
discovery learning model with RME approach and interpersonal intelligence on students' mathematics learning achievement.

Table 4. Summary of the Average Score in Each Cell

\begin{tabular}{ccccc}
\hline MODEL & High & INTERPERSONAL INTELLIGENCE & Low & Total of Average \\
& 75.478 & Medium & 62.256 & 55.238 \\
DL-RME & 53.385 & 50.146 & 38.963 & 64.324 \\
Langsung & 64.432 & 56.201 & 47.101 & 47.498 \\
Total of Average & & &
\end{tabular}

The difference can be seen from the average of students' Mathematics achievement test, the average score of students in the experimental class using discovery learning model with RME approach is 64.324, while the mean score of the students in the control class using the direct learning model is 47.498 . The difference in the average score indicates that the implementation of discovery learning model using RME has better learning achievement Mathematics than direct learning model. The importance of applying the appropriate learning model has been discussed by some previous researchers.

Learning is one of the factors that can determine students' learning outcomes [14]. Implementation of learning cannot be separated from the use of learning models and approaches. Applying an appropriate learning model will have a significant effect on the students' achievement. The results of this study indicates that the discovery learning model with RME approach gives better mathematics learning achievement than direct learning model. In line with In'am, learning geometry through discovery learning with a scientific approach can significantly improve the students' abilities [15]. Maarif summarized the results of his research that the students are learning while practicing. It is more easily due to the implementation of discovery method. They can immediately see the object and then summarize it through an easy question that is on the worksheet (Student Works Sheet) provided by the teacher [16]. The effectiveness of the discovery learning model in Mathematics learning cannot be separated from the learning steps that encourage the students to actively explore various information and knowledge through scientific activities. Ramdhani states that one of the benefits that can be gained from discovery learning is the emergence of students' scientific attitudes, such as objective attitude and the curiosity to solve problems well, and their critical thinking [17]. The curiosity causes them to be more eager to learn and know their knowledge. The use of the RME approach in the discovery learning model enables the students to explore Mathematics knowledge with scientific activities to find ideas or mathematical concepts through real problems. In line with the results of Nurhayati, STAD is a cooperative learning model where the students learn together in heterogeneous groups, meanwhile, RME learning method starts with real-world problems. Thus, STAD's cooperative learning with RME approach enables students to understand complex and abstract concepts [18]. Zakaria in his study concluded that the use of Realistic Mathematics Education (RME) approach can improve the students' achievement. The result of this study to some extent provides information in which students were taught using the RME approach are better than those that were taught using a traditional approach [19].

Table 5. Pairwise Comparison Results

\begin{tabular}{llccccc}
\hline$(\mathrm{I}) \mathrm{KI}$ & $(\mathrm{J}) \mathrm{KI}$ & Mean Difference $(\mathrm{I}-\mathrm{J})$ & Std. Error & Sig. $^{{ }^{a}}$ & Lower Bound & Upper Bound \\
\hline \multirow{2}{*}{ High } & Medium & $8.230^{*}$ & 3.349 & .015 & 1.620 & 14.840 \\
& Low & $17.331^{*}$ & 3.763 & .000 & 9.904 & 24.758 \\
\multirow{3}{*}{ Medium } & High & $-8.230^{*}$ & 3.349 & .015 & -14.840 & -1.620 \\
& Low & $9.101^{*}$ & 3.383 & .008 & 2.423 & 15.779 \\
& High & $-17.331^{*}$ & 3.763 & .000 & -24.758 & -9.904 \\
& Medium & $-9.101^{*}$ & 3.383 & .008 & -15.779 & -2.423 \\
\hline
\end{tabular}

Based on Table 5, it can be seen that there are differences in Mathematics learning achievement between high interpersonal intelligence category toward medium and low category. The difference of learning achievement is between medium and low interpersonal intelligence category. The differences of students' achievement in each category of interpersonal intelligence can be seen from the significant value. Both high and medium category of interpersonal intelligence have significant value $=0.015<0.05$ which means that the students with high interpersonal intelligence category have better Mathematics learning achievement than those having medium category. The significant value of high to low category is $0.000<$ 0.05, it means that students having high interpersonal intelligence category have better Mathematics learning achievement than those having low category. Medium to low category have a significant value $=0.008<$ 
0.05 indicating that student having medium interpersonal intelligence get better learning achievement than those having low category. In Table 4, it can be seen that there are the difference of mean score among students with high, medium and low category interpersonal intelligence. Higher-age students had an average of 64.432, the average category had an average of 56.201, and the low category had an average of 47.101.

Learning achievement can also be influenced by the students' ability in interacting with the surrounding environment, for example, working in groups or in discussion forums. The results of this study indicate that students with high interpersonal intelligence have better Mathematics learning achievement than those with medium and low category. The students with interpersonal intelligence category are having a better Mathematics achievement than students with low category. In line with the study, [12] it can be showed that students who were taught through Interpersonal Intelligence Based Teaching Strategy (IBTS) have the higher score than other groups (control groups). Ahvan's study of multiple intelligences which includes interpersonal intelligence indicates a statistically significant relationship between multiple intelligences and academic performance of student achievement [20].

Implementing discovery learning model requires students to actively seek their own information and critical thinking in dealing with a problem. As a result, the learning model that is combined with the RME approach carries the concept of learning that begins with the experience and knowledge of students. It needs a condition to learn in groups so that the students can share experiences and knowledge of their wider mathematical concepts. Group activities require good cooperation, understanding, and adaptation skills with the character of each group member. So the ability to understand others is the better way for the students to do group work with other friends. Active and effective group work will have a positive impact on learning achievement, especially in subjects that use self-directed learning models such as discovery learning.

Based on Table 3. On model * KI has sig value $0.331>0.05$ which means there is no interaction between learning model with interpersonal intelligence. Considering the research questions 1 and 2 , it can be concluded that: 1) it is shown from each category of interpersonal intelligence, discovery learning model with RME approach is better than direct learning model; 2) it is shown that discovery learning model with RME approach of high interpersonal intelligence is better than medium or low and better than low; 3) it is shown that direct learning model of high interpersonal intelligence is better than the moderate or low to get the better intelligence

\section{CONCLUSION}

The conclusions that can be taken from the result of the research are: 1) there is a difference of student's Mathematics learning achievement between student group using discovery learning model with RME approach and direct learning, the learning discovery learning model with RME approach gives better learning achievement of Mathematics than learning direct; 2) students having high interpersonal intelligence category have better Mathematics learning achievement than those having medium and low category, students with interpersonal intelligence are having better mathematics achievement than low category students; 3) there is no interaction between discovery learning model with RME approach and interpersonal intelligence on mathematics learning achievement.

The results of this study can be used by the teachers as a consideration in applying effective learning models on Mathematics subjects. Discovery learning model with RME approach can be used by the teachers as an alternative effective learning model because it can be applied to all categories of students' interpersonal intelligence.

\section{REFERENCES}

[1] S Prince, J.M., "Inductive teaching and learning methods definitions, comparisons and research bases," J. Engr. Education, vol. 95, pp. 123-138, 2006.

[2] A.K. A. Mahmoud, "The effect of using discovery learning strategy in teaching grammatical rules to first year general secondary student on developing their achievement and metacognitive skills," International Journal of Innovation and Scientific Research, vol. 5, pp. 146-153, 2014.

[3] S. L. Wong, et al, "The effectiveness of inductive discovery learning in 1: 1 mathematics classroom," Proceedings of the 18th International Conference on Computers in Education, Asia-Pacific Society for Computers in Education, pp. 743-747, Putrajaya, Malaysia 2010.

[4] A. G. Balım, "The Effects of discovery learning on students' success and inquiry learning skills," Egitim Arastirmalari-Eurasian Journal of Educational Research, vol. 35, pp. 1-20, 2009.

[5] Hosnan, M., Scientific and contextual approach in the 21st century learning (in Bahasa), PT. Ghalia Indonesia, Bogor 2014.

[6] M.S. Sumantri, Learning strategies: theory and practice in elementary education level (in Bahasa), PT. Rajagrafindo Persada, Jakarta, 2015, pp.109. 
[7] R. Hidayat and Z. H. Iksan, "The Effect of realistic mathematic education on students' conceptual understanding of linear progamming", Creative Education, vol. 6, 2438-2445, 2015.

[8] V. Arsaythamby and C. M. Zubainur, "How a realistic mathematics educational approach affect students' activities in primary schools?," Procedia - Social and Behavioral Sciences, vol. 159, pp. 309-313, 2014.

[9] C. H. Ekowati, et al., "The application of realistic mathematics education approach in teaching mathematics in penfui kupang," International Journal of Education and Information Studies, vol. 5, pp. 35-43, 2015.

[10] H. Gardner, Inteliigence reframed: multiple intelligences for the $21^{\text {st }}$ century, New York: Basic Books, 1999, pp. 43.

[11] F. Behjat, "Interpersonal and intrapersonal intelligences: Do they really work in foreign-language learning?," Social and Behavioral Sciences, vol. 32, pp. 351-355, 2012.

[12] V. Advani, and G. Hema, "Effect of interpersonal intelligence based teaching strategies on students academic achievement," The International Journal of Indian Psychology, vol. 3, pp.119-128, 2016.

[13] Budiyono, Statistics for research (in Bahasa), Surakarta: UNS Press, 2015, pp. 168-177.

[14] D. H. Lim, dan M.L. Morri., "Learner and instructional factors influencing learning outcomes within a blended learning environment," Educational Technology \& Society, vol.12, pp. 282-293, 2009.

[15] A. In'am. and Siti Hajar, "Learning geometry through discovery learning using a scientific approach," International Journal of Instruction, vol.10, pp. 55-70, 2017.

[16] S. Maarif, "Improving junior high school students' mathematical analogical ability using discovery learning method," International Journal of Research in Education and Science (IJRES), vol. 2, pp. 114- 124, 2016.

[17] M.R. Ramdhani, et al., "Discovery Learning with Scientific Approach on Geometry," International Conference on Mathematics and Science Education (ICMScE), IOP Conf. Series: Journal of Physics: Conf. Series 895, pp. 1-6, 2017.

[18] D. M. Nurhayati and Hartono, "Implementation of cooperative learning model type stad with rme approach to understanding of mathematical concept student state Junior High School in Pekanbaru," AIP Conf. Proc. 1848, pp. 040002-1-040002-5, 2017.

[19] E. Zakaria and S, "The effect of realistic mathematics education approach on students' achievement and attitudes towards mathematics," International Scientific Publications and Consulting Services, vol. 2017, pp. 32-40, 2017.

[20] Y. R. Ahvan and H. Z. Pour, "The correlation of multiple intelligences for the achievements of secondary students," Academic Journal, vol. 11, pp. 141-145, 2016. 